\title{
Measurement of water-use by Jatropha curcas L. using the heat-pulse velocity technique
}

\author{
MB Gush* \\ CSIR, \% Agrometeorology, School of Environmental Sciences, University of KwaZulu-Natal, Private Bag X01, \\ Scottsville 3209, South Africa
}

\begin{abstract}
In response to the proposed introduction of the potential bio-diesel species Jatropha curcas (Linnaeus) to South Africa, field experiments were conducted to investigate its likely water-use impacts relative to other forms of vegetative land use. As no existing water-use data could be found for this species worldwide, sap flow in Jatropha curcas trees was measured continuously for a 17-month period at two sites in eastern South Africa. These consisted of young (4-year-old) trees at a relatively wet site and mature (12-year-old) trees at a dry site. The heat-ratio method of the heat-pulse technique was utilised, together with measurements of meteorological variables and soil water. Sap- flow rates varied according to tree age, season, prevailing meteorological conditions, and soil moisture levels. Peak sapflow rates occurred during the warm wet summer months, but due to the deciduous nature of the species, water use was negligible during winter. Scaled-up sap-flow measurements resulted in estimates of total annual transpiration of $1983 \ell(147 \mathrm{~mm})$ for a 4 -year-old $J$. curcas tree, and $4884 \ell(362 \mathrm{~mm})$ for a 12-year-old $J$. curcas tree. The study concluded that the $J$. curcas trees studied were conservative in their water use, and were unlikely to transpire more water than indigenous vegetation types of the area.
\end{abstract}

Keywords: heat ratio method, sap flow, transpiration, water resource impacts

\section{Introduction}

In response to rising oil prices and the quest for alternative, economically viable and environmentally sustainable forms of energy, certain plant species with bio-energy potential have been proposed for large-scale planting and bio-fuel production. International interest in Jatropha curcas as a drought- tolerant, fastgrowing, renewable bio-energy crop has grown significantly in recent years. Countries such as India have initiated large-scale plantings of $J$. curcas in efforts towards the increased use of bio-diesel as an alternative to fossil fuel imports (Francis et al., 2005). In South Africa, the government has received numerous requests for permission to plant this species, but, apart from certain trial plantings, has imposed a moratorium on commercial plantings. This has been due to, amongst other considerations, the extremely limited data available on its potential environmental impacts (specifically water-use). This knowledge gap is of particular concern in a dry country such as South Africa, where evapotranspiration from vegetation is the component of the water balance that accounts for the greatest loss of water from catchments. Accurate estimates of water-use are therefore fundamental to gaining a good understanding of the hydrological impacts of a specific plant species or vegetation type. Where large-scale changes in vegetation cover are being proposed, this aspect becomes particularly important because the difference in evapotranspiration between the current and the proposed vegetation will be directly related to changes in available water in that catchment (ultimately streamflow). Consequently, large-scale changes in land use could have significant hydrological implications if the water use of the introduced species were significantly

\footnotetext{
* To whom all correspondence should be addressed

e-mail:mgush@.csir.co.za
}

different to that of the vegetation it would replace.

In this study, sap-flow measurements of young (4-year-old) and mature (12-year-old) Jatropha curcas trees were conducted to assess the water-use trends of this species relative to other forms of vegetative land use. Plant sap flow (transpiration) was measured using the heat-pulse technique, together with measurements of meteorological variables and soil moisture at two sites in KwaZulu-Natal Province, South Africa (Gush and Moodley, 2007).

\section{Materials and methods}

\section{Site selection}

Two monitoring sites were selected along the subtropical eastern seaboard of South Africa within the KwaZulu-Natal (KZN) Province (Fig. 1). These sites consisted of:

- 4-year-old Jatropha curcas trees at the Owen Sithole College of Agriculture near Empangeni

- 12-year-old Jatropha curcas trees at a homestead in the Makhathini flats, northern KZN.

The Owen Sithole College of Agriculture (OSCA) is located approximately $20 \mathrm{~km}$ north-west of Empangeni, in the KZN province of South Africa. The identified monitoring site (grid reference S $28^{\circ} 38^{\prime} 36.7^{\prime}$; E $31^{\circ} 55^{\prime} 36^{\prime}$ and altitude $44.2 \mathrm{~m}$ a.m.s.l.) consisted of a $J$. curcas trial planted in January 2002. It was a valley-bottom site, close to a stream but non-riparian, being approximately $30 \mathrm{~m}$ from the stream channel. The site was maintained under controlled conditions (weed control, but no irrigation), and consisted of $24 \mathrm{~J}$. curcas trees planted in two blocks of $6 \mathrm{X} 2$ trees. Spacing was $4.5 \mathrm{~m}$ (between rows) by $3.0 \mathrm{~m}$ (within rows). The trees were $2.5 \mathrm{~m}$ tall, had stem diameters of approximately $0.1 \mathrm{~m}$ at a stem height of $0.15 \mathrm{~m}$ when 


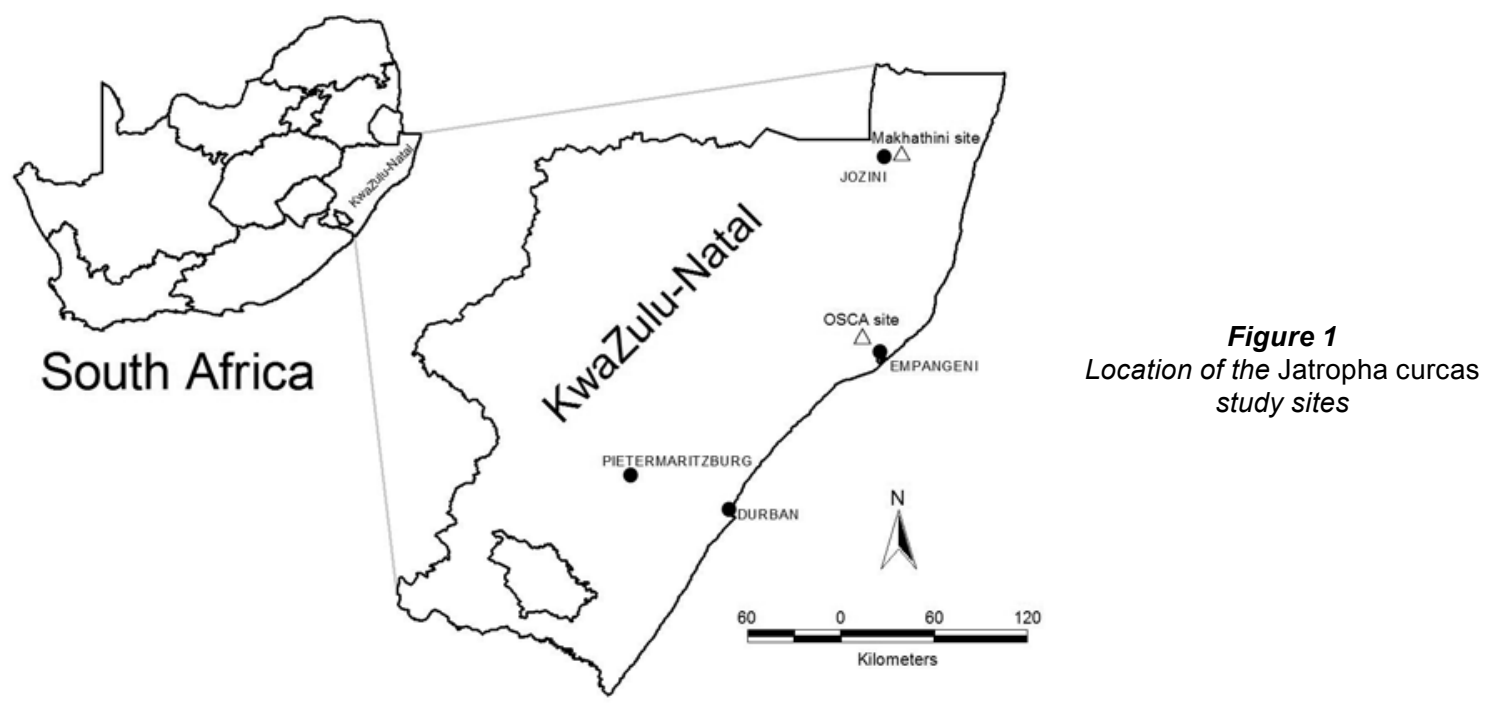

monitoring commenced on 27 January 2005. Leaf area index (LAI) measurements taken with a Li-COR LI-2000 Plant Canopy Analyser in mid-December 2005 (when leaf area was at a maximum) gave an LAI of 1.28 for the trees. Continuous measurements of sap flow (transpiration) and meteorological variables (rainfall, solar radiation, air temperature, relative humidity, wind speed and wind direction) were taken hourly for a 17-month period from $2^{\text {nd }}$ February 2005 until $27^{\text {th }}$ June 2006. The weather station was located approximately $2 \mathrm{~m}$ from the trees. Sensors were mounted $2 \mathrm{~m}$ above the ground, and variables were continuously measured at $10 \mathrm{~s}$ intervals, and averaged or totalled at hourly intervals. Continuous measurements of soil-water content were carried out at the OSCA site using CS616 probes (Campbell Scientific, Logan, UT). No soil-moisture measurements were taken at the Makhathini site.

The Makhathini site consisted of mature J. curcas trees situated along the fence-line of a rural homestead in the Makhathini flats region of Northern KZN. The site (grid reference S $27^{\circ}$ 24' 06.9'; E $32^{\circ} 11^{\prime}$ '48.6' and altitude $75.2 \mathrm{~m}$ a.m.s.1.) was nonriparian and was situated approximately $20 \mathrm{~km}$ east of Jozini, KZN Province, close to the Makhathini Agricultural Research Station. Based on anecdotal evidence from local inhabitants the trees were estimated to be approximately 12 years old (planted January 1994). The trees were approximately $6 \mathrm{~m}$ tall with an LAI of 2.26 measured in mid-December 2005. Sap flow and selected meteorological variables (temperature, relative humidity and solar radiation) were measured hourly at the Makhathini site for a 16-month period from $5^{\text {th }}$ March 2005 until $2^{\text {nd }}$ July 2006.

\section{Sap-flow measurements}

The heat-pulse velocity (HPV) technique is recognised internationally as an accepted method for the measurement of sap flow in woody plants and has been extensively applied in South Africa (Dye and Olbrich, 1993; Dye, 1996; Dye et al., 1996). The heat ratio method (HRM) of the HPV technique (Burgess et al., 2001) was selected because of its ability to measure low rates of sap flow, often characteristic of plants growing under dry conditions typically experienced in South Africa. Sap-flow monitoring systems were installed in two trees at each site, using thermocouple pairs and heater probes inserted to different depths within the sapwood to determine radial variations in sap flow. Due to the fast-growing nature of Jatropha curcas the probes were completely removed and repositioned to their correct depths at the

start of the growing season (October), and then rechecked periodically during the course of the monitoring period. A CR10X data-logger connected to two AM16/32 multiplexers (Campbell Scientific, Logan, UT) was programmed to initiate the heat pulses and record hourly data from the respective thermocouple pairs. Cellular phone modems connected to the loggers allowed remote downloading of data as well as uploading of programmes to the logger.

\section{Sap-flow data analysis}

Once sap-flow monitoring had been completed, additional supplementary information required to complete the HPV data analysis was collected. All meteorological data were aggregated into daily, monthly and annual totals. Measurements of sapwood area, sapwood moisture content, wood density and the width of wounded (non-functional) xylem around the thermocouples ('wound widths') were conducted on the trees. The trees could not be destructively sampled as they constituted an agricultural research trial, so wood samples and tree cores were taken to determine these variables.

Measured heat-pulse velocities were corrected for sapwood wounding caused during the drilling procedure, using woundcorrection coefficients described by Swanson and Whitfield (1981). The corrected heat-pulse velocities were then converted to sap-flux densities according to the method described by Marshall (1958). Finally, the sap-flux densities were converted to whole-tree total sap flow by calculating the sum of the products of sap-flux density and cross-sectional area for individual tree stem annuli (determined by below-bark individual probe insertion depths and sap-wood depth). Hourly sap-flow values were aggregated into daily, monthly and annual totals for both trees at each site.

\section{Results}

\section{Meteorological variables}

Monthly variations in mean maximum and minimum temperature, total rainfall and total solar radiation measured at OSCA and Makhathini are illustrated in Figs. 2 and 3 respectively.

Although average maximum and minimum air temperatures at both sites declined from April onwards, they never dropped below $24.4^{\circ} \mathrm{C}$ and $9^{\circ} \mathrm{C}$ respectively. The lowest recorded temperature for the entire monitoring period was $2.3^{\circ} \mathrm{C}$ on 17 June 


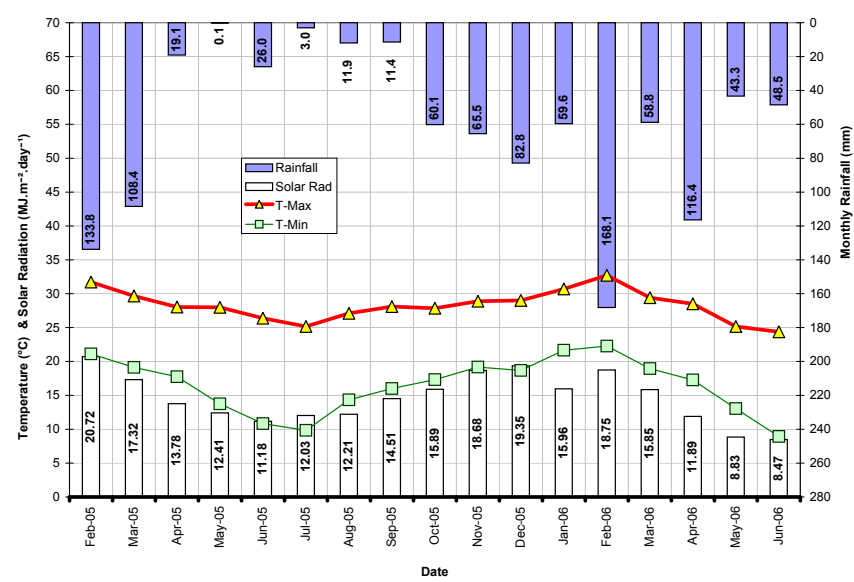

Figure 2

Monthly values of meteorological variables recorded between February 2005 and June 2006 at the OSCA site

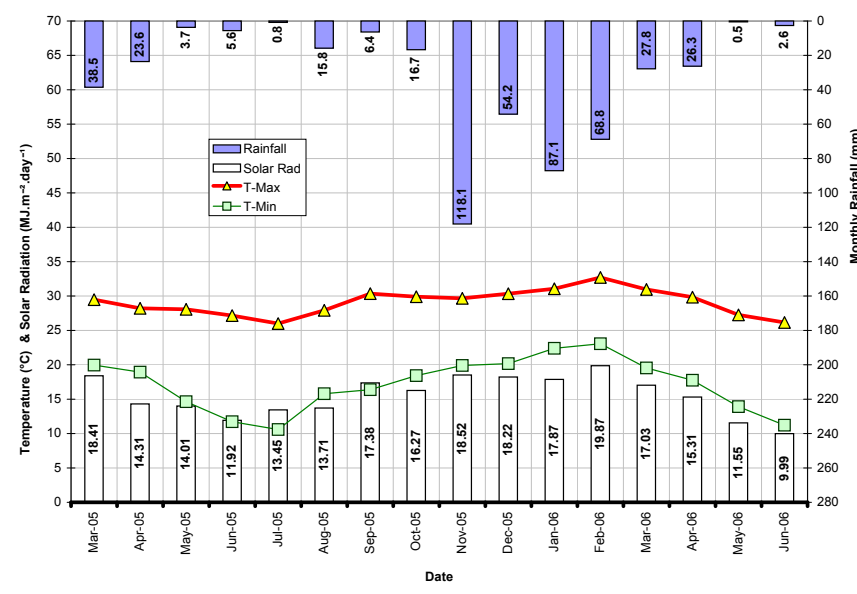

Figure 3

Monthly values of meteorological variables recorded between March 2005 and June 2006 at the Makhathini site

2005 at $\operatorname{OSCA}\left(5.3^{\circ} \mathrm{C}\right.$ on 17 June 2005 at Makhathini), while the highest recorded temperature was $41.3^{\circ} \mathrm{C}$ on 2 November 2005 at OSCA $\left(41.0^{\circ} \mathrm{C}\right.$ on 2 October 2005 at Makhathini). Mean annual temperature was $22.5^{\circ} \mathrm{C}$ for OSCA and $23.4^{\circ} \mathrm{C}$ for Makhathini, and average daily solar radiation over the entire period was 15.2 $\mathrm{MJ} \cdot \mathrm{m}^{-2} \cdot \mathrm{d}^{-1}$ at OSCA and $16.1 \mathrm{MJ} \cdot \mathrm{m}^{-2} \cdot \mathrm{d}^{-1}$ at Makhathini. These warm and sunny conditions reflected the hot and dry sub-tropical climate of the study sites, providing suitable growing conditions for $J$. curcas. Wind speeds were generally low, averaging $1.3 \mathrm{~m} \cdot \mathrm{s}^{-1}$ at the OSCA site and $1.2 \mathrm{~m} \cdot \mathrm{s}^{-1}$ at the Makhathini site. Rainfall was significantly more variable. For the same calendar year used to calculate transpiration totals (March 2005 to February 2006) rainfall amounted to just $618 \mathrm{~mm}$ at OSCA and $440 \mathrm{~mm}$ at Makhathini. These totals were significantly below the long-term means of $1016 \mathrm{~mm}$ for OSCA and $582 \mathrm{~mm}$ for Makhathini (Lynch and Schulze, 2006) and these dry conditions were a consideration in the interpretation of the results of this study. Reference evapotranspiration (ET), as calculated using the FAO56 method (Allen et al., 2004), was $1251.7 \mathrm{~mm}$ for the
OSCA site and $1310.7 \mathrm{~mm}$ for the Makhathini site (Table 1). Daily values ranged from a maximum of approximately $8 \mathrm{~mm}$ in summer to $1 \mathrm{~mm}$ in winter at both sites.

\section{Sap flow}

Over a calendar year (March 2005 to February 2006) the sapflow totals for the sample trees at OSCA were $1899 \mathrm{~kg}(\ell)$ and $1983 \mathrm{~kg}$ for Trees 1 and 2. Individual tree sap-flow values were scaled up to represent a larger area (i.e. a J. curcas plantation). Tree spacing at the OSCA study site $(3 \mathrm{~m}$ by $4.5 \mathrm{~m})$ translated into a planting density of 740 stems per hectare (spha). By scaling the individual tree sap-flow measurements up to a hectare, and converting to mm-equivalent, sap-flow (transpiration) totals were calculated to be $140.6 \mathrm{~mm}$ and $146.9 \mathrm{~mm}$ for Trees 1 and 2. A similar exercise was conducted for the Makhathini site. Some assumptions were required because the sample trees consisted of just a single row of 10 trees along the homestead fence. These trees were spaced approximately $3 \mathrm{~m}$ from each other (as at OSCA), and so a similar planting density to the OSCA site was assumed (740 spha) despite the absence of additional rows of trees. Consequently it is possible that the scaled-up sap-flow rates calculated here are slightly higher than would be experienced in a plantation environment, as a result of reduced competition for light, water and nutrients. The annual sap-flow totals for the Makhathini trees were $4884 \mathrm{~kg}$ and $4036 \mathrm{~kg}$ for Trees 1 and 2, which translated into totals of $361.8 \mathrm{~mm}$ and $298.9 \mathrm{~mm}$ for Trees 1 and 2, given the planting density. Daily fluctuations in sap-flow (transpiration) $\left(\mathrm{kg} \cdot \mathrm{d}^{-1}\right)$ for the trees at the OSCA and Makhathini sites are shown in Figs. 4 and 5.

\section{Discussion and conclusions}

Sap-flow rates in the $J$. curcas trees were season-dependent due largely to the deciduous nature of the species, although day length and rainfall had an effect on the seasonal pattern (Figs. 4 and 5). Daily sap-flow totals fluctuated widely due to changes in energy availability (solar radiation) and VPD, but

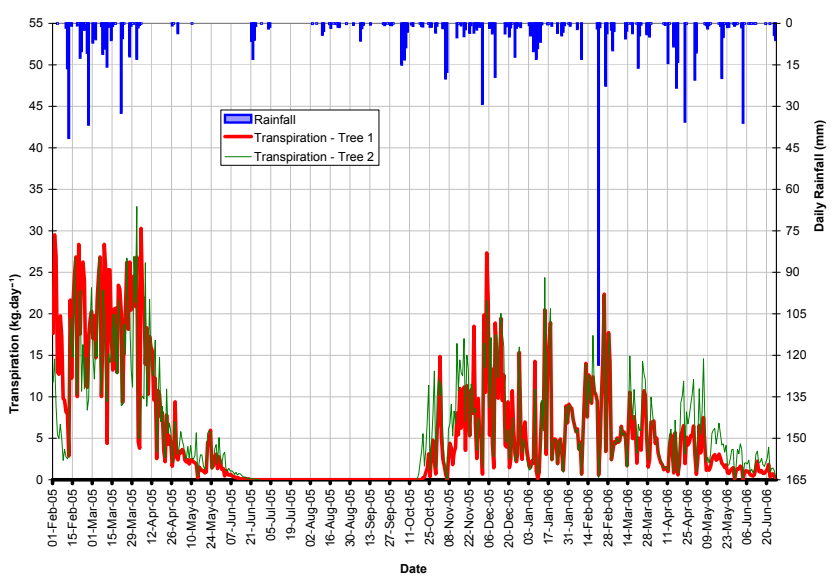

Figure 4

Daily sap-flow totals $\left(\mathrm{kg}^{\left.-\mathrm{d}^{-1}\right)}\right.$ for two 4-year-old Jatropha curcas trees, and rainfall at the OSCA site, between February 2005 and June 2006

\section{TABLE 1}

Monthly reference evapotranspiration totals (ET, at the OSCA and Makhathini sites

\begin{tabular}{|l|c|c|c|c|c|c|c|c|c|c|c|c|c|}
\hline & Mar & Apr & May & Jun & Jul & Aug & Sep & Oct & Nov & Dec & Jan & Feb & Total \\
\hline OSCA & 118.4 & 123.6 & 112.8 & 84.9 & 72.8 & 60.3 & 65.0 & 99.8 & 117.9 & 124.7 & 133.3 & 137.8 & 1251.2 \\
\hline Makh. & 134.9 & 130.4 & 104.1 & 91.0 & 82.3 & 68.0 & 71.5 & 92.3 & 124.8 & 132.1 & 134.9 & 144.4 & 1310.7 \\
\hline
\end{tabular}




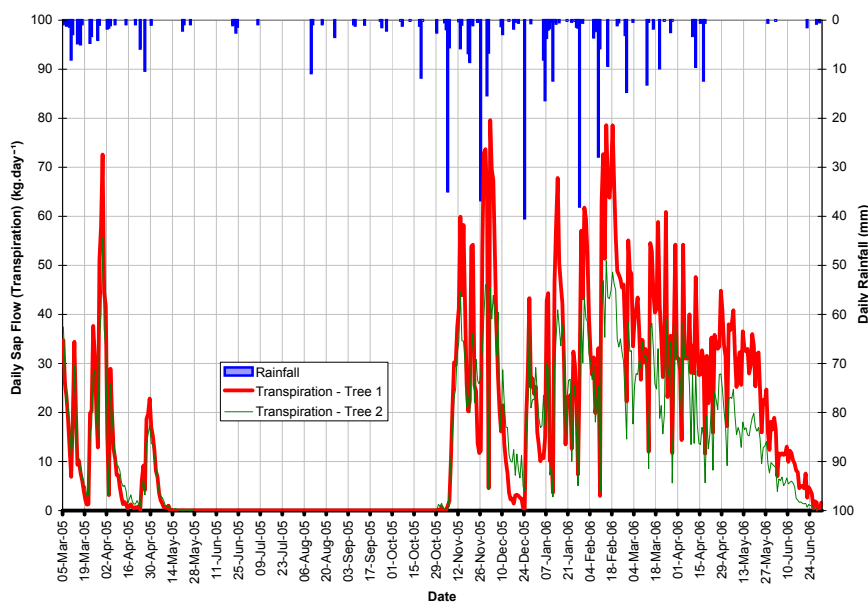

Figure 5

Daily sap-flow totals $\left(\mathrm{kg}^{\left.-\mathrm{d}^{-1}\right)}\right.$ for two 12-year-old Jatropha curcas trees, with rainfall at the Makhathini site, between March 2005 and June 2006

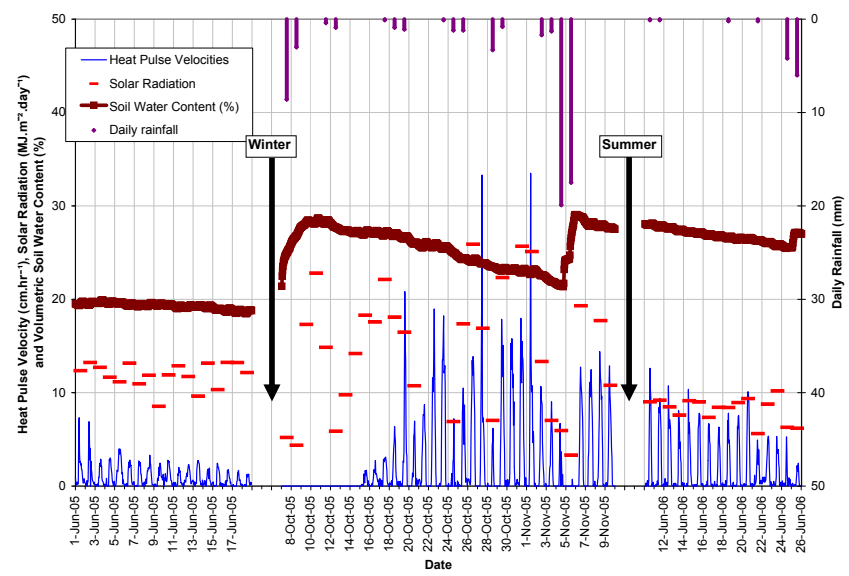

Figure 6

Hourly heat-pulse velocities $\left(\mathrm{cm} \cdot h^{-1}\right)$ recorded at the OSCA site, with corresponding solar radiation $\left(M J \cdot m^{-2} \cdot h^{-1}\right)$, volumetric soil water content $(\%)$ and daily rainfall $(\mathrm{mm})$ fluctuations

also potentially due to the timing and amount of individual rainfall events, and their replenishing effect on soil moisture availability. The highest daily sap-flow totals recorded at the OSCA site were $30.3 \mathrm{~kg} \cdot \mathrm{d}^{-1}$ (Tree 1) and $32.9 \mathrm{~kg} \cdot \mathrm{d}^{-1}$ (Tree 2), while daily averages over a full year (March 2005 - February 2006) were $5.2 \mathrm{~kg} \cdot \mathrm{d}^{-1}$ and $5.4 \mathrm{~kg} \cdot \mathrm{d}^{-1}$ respectively. Maximum sap-flow rates in summer contrasted with a cessation of sap flow in the cooler and drier winter months. The declining sap flows observed closer to the winter months, resulted from a combination of meteorological conditions (lower temperatures and reduced solar radiation), changing tree physiological conditions (leaf drop) and declining soil-water content. An increase in sap flow after winter dormancy coincided closely with the first good rains, the development of new leaves and the onset of warmer/wetter conditions in mid- to late October.

Figure 6 illustrates seasonal changes in heat-pulse velocities recorded in the $J$. curcas trees at the OSCA site in relation to changing meteorological conditions (solar radiation and rainfall) and soil water contents (average of 3 sample depths). Three periods are illustrated during which significant changes in sap flow were observed, namely transition periods at the onset of winter dormancy (June 2005), at the start of the summer growing season (Oct/Nov 2005), and at a corresponding period during the following winter (June 2006). After winter dormancy the first flush of new leaves occurred soon after the onset of warmer, wetter conditions early in October 2005. The resumption of sap flow was detected from 16 October 2005 onwards. Higher (although more variable) solar radiation and soil-water contents characterised this summer period. Sap flow on days of significant rainfall (e.g. 5/6 November $2005-37.4 \mathrm{~mm}$ ) was low due to energy constraints resulting from reduced solar radiation because of clouds, low atmospheric VPD and wet leaves. However, within a day or two thereafter responses to the additional soil water provided by these events were manifested through increased sap-flow rates. Sap flow towards the end of the second growing season (June 2006) was sustained for longer than during the preceding year and appears to be the result of greater soil-water availability.

J. curcas sap-flow rates at the Makhathini site appeared to be highly rainfall-dependent (Fig. 5). This is possibly as a result of the sandy soils found in this area, which would have rapid drainage and a low capacity to retain water near the surface where the bulk of the tree roots are. Consequently, individual rainfall events initiated rapid responses in sap flow as the trees made use of the readily available soil moisture. However, as the water drained or evaporated from the sandy soils, so the sapflow rates declined markedly, until the next rainfall event. This trend was most dramatic at the start of the hydrological year (October - January), but became less so towards the end (February - July). The highest daily sap-flow totals recorded at the Makhathini site were $79.6 \mathrm{~kg} \cdot \mathrm{d}^{-1}$ (Tree 1) and $55.5 \mathrm{~kg} \cdot \mathrm{d}^{-1}$ (Tree 2), while daily averages over a calendar year (March 2005 to February 2006) were $13.4 \mathrm{~kg} \cdot \mathrm{d}^{-1}$ (Tree 1) and $11.1 \mathrm{~kg} \cdot \mathrm{d}^{-1}$ (Tree 2). Tree 1 at Makhathini was observed to transpire more water than Tree 2. When the probes were removed from the trees at the end of the monitoring period, it was noticed that Tree 2 had an area of dead wood in one part of the stem, and it is possible that this had an impact on the overall water-use of that tree and the estimation of whole-tree sap flow.

Although the HPV data for the Makhathini site showed similar seasonal patterns to that of the OSCA site, there were some noticeable differences between the two sites. Firstly, the Makhathini HPV data declined far more dramatically and significantly earlier in the winter season. While the 4-year-old trees at OSCA continued transpiring until mid-June 2005, the older Makhathini trees showed no signs of sap flow after the $15^{\text {th }}$ of May 2005. Periods of water stress as early as mid-March and during the second half of April (characterised by decreasing sap flow) were alleviated by individual rainfall events. The differences in total water use between the $J$. curcas trees at OSCA and those at Makhathini could not be attributed to prevailing climatic conditions alone, as monthly values of reference evapotranspiration (ET) were similar for the two sites. Although the OSCA trees had noticeably higher sap-flow rates, presumably due to their young age and increased vigour; in terms of total volumetric water-use they were surpassed by the older and larger Makhathini trees with a greater leaf area.

It should be borne in mind that these results were obtained under conditions of below-average rainfall, especially at the OSCA site, where rainfall for the year was just $61 \%$ of the annual mean. Under these conditions and at dry sites such as Makhathini, annual sap flow will be low and constrained by low available water and the deciduous nature of the species. Nevertheless, at a higher rainfall site, the deciduous habit is still going to constrain annual evapotranspiration. From the observed results it was concluded that $J$. curcas trees are conservative in their water use and comparable to that of indigenous vegetation types which exhibit seasonal senescence (e.g. grassland), and 
significantly less than evergreen vegetation that is capable of transpiring year-round (e.g. exotic plantation forestry species).

\section{Acknowledgements}

Project funding from the Water Research Commission of South Africa is gratefully acknowledged. Staff from the KwaZuluNatal Dept. of Agriculture and Environmental Affairs (DAEA), specifically Mr. Francois du Toit, Mr. Jabulani Mdluli, Mr. Ben Koranteng and Mr. Diliza Masinga are thanked for assistance with site selection and maintenance. Appreciation is also extended to the Sithole family, for allowing the monitoring of Jatropha curcas trees at their homestead in the Makhathini area; and to colleagues Prof. Colin Everson, Dr. Mags Moodley, Mr. Alistair Clulow and Mr. Joshua Xaba for technical advice and assistance in the field.

\section{References}

ALLEN RG, PEREIRA LS, RAES D and SMITH M (2004) Crop evapotranspiration: Guidelines for computing crop water requirements. FAO Irrig. Drain. Paper 56. FAO, Rome.

BURGESS SSO, ADAMS MA, TURNER NC, BEVERLY CR, ONG CK, KHAN AAH and BLEBY TM (2001) An improved heat pulse method to measure low and reverse rates of sap flow in woody plants. Tree Physiol. 21 589-598.
DYE PJ (1996) Response of Eucalyptus grandis trees to soil-water deficits. Tree Physiol. 16 233-238.

DYE PJ and OLBRICH BW (1993) Estimating transpiration from 6-year-old Eucalyptus grandis trees: development of a canopy conductance model and comparison with independent sap flux measurements. Plant Cell Environ. 16 45-53.

DYE PJ, SOKO S and POULTER AG (1996) Evaluation of the heat pulse velocity method for measuring sap flow in Pinus patula. J. Exp. Bot. 47 975-981.

FRANCIS G, EDINGER R and BECKER K (2005) A concept for simultaneous wasteland reclamation, fuel production, and socioeconomic development in degraded areas in India: Need, potential and perspectives of Jatropha plantations. Nat. Resour. Forum 29 12-24.

GUSH MB and MOODLEY M (2007) Water use assessment of Jatropha curcas. In: Holl M, Gush MB, Hallowes J and Versfeld DB (eds.) Jatropha curcas in South Africa: An Assessment of its Water Use and Bio-Physical Potential. WRC Report No. 1497/1/07 (Chapter 4). Water Research Commission, Pretoria, RSA.

LYNCH SD and SCHULZE RE (2006) Rainfall Databases. In: Schulze RE (ed.) South African Atlas of Climatology and Agrohydrology. WRC Report No. 1489/1/06 (Section 2.2) Water Research Commission, Pretoria, RSA.

MARSHALL DC (1958) Measurement of sap flow in conifers by heat transport. Plant Physiol. 33 385-396.

SWANSON RH and WHITFIELD DWA (1981) A numerical analysis of heat pulse velocity theory and practice. J. Exp. Bot. 32 221-239. 
Available on website http://www.wrc.org.za ISSN 0378-4738 = Water SA Vol. 34 No. 5 October 2008 ISSN 1816-7950 = Water SA (on-line) 